\title{
Probiotic environmentalities: rewilding with wolves and worms
}

\section{Jamie Lorimer}

School of Geography and the Environment, University of Oxford

jamie.lorimer@ouce.ox.ac.uk

South Parks Road, OX1 3QY, UK.

\begin{abstract}
A probiotic turn is underway in the management of human and environmental health. Modern approaches are being challenged by deliberate interventions that introduce formerly taboo life forms into bodies, homes, cities and the wider countryside. These are guided by concepts drawn from the life sciences, including immunity and resilience. This analysis critically evaluates this turn, drawing on examples of rewilding nature reserves and reworming the human microbiome. It identifies a common ontology of socio-ecological systems marked by anthropogenic absences and tipped across thresholds into less desirable states. It examines the operation of an environmental mode of biopower associated with deliberate efforts to engineer ecologies through the introduction of keystone species. It offers a set of criteria for critically evaluating the degree to which these interventions transform or sustain prevalent forms of late modern biopolitics. The conclusion reflects on the potentials of probiotic environmentalities for hospitable government beyond the Anthropocene.
\end{abstract}




\section{A probiotic turn}

Securing the human through the control of unruly ecologies is one of the defining objectives of the period becoming known as the Anthropocene. Bodies have been purified, homes sanitized and some environments made safe, productive and orderly. Scientific and political developments in the $19^{\text {th }}$ and $20^{\text {th }}$ centuries led to the eradication of diseases, economic growth and food surpluses. Modern hygiene has made some lives better. But in recent decades environmental and medical experts have argued that this 'antibiotic' approach has become excessive. It is suggested that obsessions with purity, division, simplicity and control are driving the emergence of new pathologies.

Environmental scientists have flagged the 'pathologies' of modern modes of natural resource management (Holling and Meffe, 1996; Hinchliffe et al., 2016). They argue that the eradication of species and the rationalisation of environmental processes (like fire, flood and disease) undermine the functionality of ecological systems. Such thinking has been echoed in more recent discussions of the human microbiome (HMP, 2012). Emerging maps of the microbial life in us are beginning to specify established concerns that modern lifestyles have degraded our inner ecologies. We are warned that 'missing microbes' (Blaser, 2014) might account the dramatic recent increases in allergic, inflammatory and autoimmune disease.

In response to these concerns, there is a now a growing interest across a range of policy domains in the 'probiotic' introduction of formerly taboo entities into our bodies, homes, cities and the wider countryside. I use the label probiotic in an expansive sense to encompass interventions that are explicitly framed in contrast to 
modern, antibiotic approaches to health and environmental management. Examples extend from the rise of 'probiotic' diets (e.g. Sonnenburg and Sonnenburg, 2015), to established forms of 'organic' farming and 'biological' means for pest control (Hajek, 2004), to the rise of 'rewilding' in nature conservation (Lorimer et al., 2015) and practices of 'managed realignment' in flood defence (Esteves, 2014). These practices are still marginal, they are contested, and they differ in important ways. But this probiotic turn is intellectually and politically significant for understanding late modern human-environment relations.

To date there has been little systematic research on these trends and the mode of government they represent. This paper begins to address this gap. To do so it compares developments in two sets of case studies, which it takes as exemplary of the probiotic turn as it is manifested in the 'macro' and the 'micro' biome. The first is 'rewilding' and the introduction of ecologically significant 'keystone species’ (like wolves) for landscape scale nature conservation. The second is 'helminthic therapy' and the introduction of parasitic worms into the human body to address autoimmune and inflammatory diseases.

Having outlined these examples, the paper reflects on three broad themes that help specify the character of the probiotic turn. It first identifies components of a common ontology associated with these interventions. Here human bodies and natural landscapes comprise dynamic and unstable ecologies. These ecologies are marked by anthropogenic absences, which have tipped them across thresholds into less desirable states. Second the paper draws on recent literatures on biopolitics and biosecurity, to identify a probiotic ‘environmentality’ (after Foucault, 2010) - or ‘environmental’ 
mode of biopower - associated with deliberate efforts to engineer ecologies through the introduction of keystone species. It identifies common techniques through which such species are used to reconfigure their target ecology, tipping these across thresholds to secure desired functions. Third the paper offers a set of criteria for critically evaluating the political and ecological objectives of these interventions, focusing on the degree to which they 'sustain' or 'transform' (after Nelson, 2014) the unequal, proprietorial and anthropocentric character of prevalent forms of late modern biopolitics. In conclusion, the paper reflects on the potential of the probiotic turn for developing hospitable government within and beyond the Anthropocene.

\section{Rewilding}

Critics have argued that $20^{\text {th }}$ century nature conservation was too conservative in its efforts to fix ecologies in the face of rapid land use change (Hobbs et al., 2013). They argue that this model of conservation has had limited success and might be pathological as a response to the fast-changing ecologies of the Anthropocene (for discussion see (Marris, 2011 and critical responses in Wuerthner et al., 2014). A growing number of ecologists and conservationists now describe a planet of ‘anthromes’ (Ellis, 2011) or 'novel ecosystems’ (Hobbs et al., 2013), nonequilibrium ecologies resulting from accelerated climate change, the spread of invasive species, and anthropogenic land use.

It is in this context that rewilding is emerging as a hot topic in nature conservation. Rewilding shifts the focus of conservation from species composition to ecological processes and functions. It also moves the target baselines of conservation from premodern to prehistorical landscapes (for overviews and critical commentary see 
Lorimer et al., 2015; Svenning et al., 2016; Lorimer and Driessen, 2016). Interventions in the name of rewilding generally seek to (re)introduce 'keystone species': 'species that play a disproportionately large role in the prevalence and population levels of other species within their ecosystem or community' (Wagner, 2010: 51). Predators and large herbivores are deployed as 'ecological engineers' capable of instigating processes with desired landscape scale impacts. Continental scale schemes have been proposed to rewild Europe (Pereira and Navarro, 2015) and North America (Foreman, 2004).

Apex predators feature prominently in North American versions of rewilding. Perhaps the most famous example being the reintroduction of wolves into Yellowstone National Park in the USA. The Grey Wolf (Canis lupis) was once one of the world's most widely distributed mammals. But it was eradicated from Yellowstone (and most of North America and Europe) by the 1920s. Populations of herbivores like elk (Cervus elaphus) subsequently boomed and significant changes in vegetation were noted. This is a classic example of what biologists term a 'trophic cascade' (Terborgh and Estes, 2010) where the absence of an apex predator at the top of the food chain results in widespread and seemingly disproportionate ecological shifts.

Wolves were reintroduced to Yellowstone in 1995. This intervention sought to save a charismatic species, but it was also guided by a desire to intervene into the ecosystem to redress the past cascade. As wolf populations grew so those of elk reduced by over 50\% (Ripple and Beschta, 2004). There has been an increase in the new-growth of aspen and willow on the valley bottoms and in populations of beaver and bison. Biologists suggest these shifts relate in part to direct predation, but more significantly 
to changes in elk behaviour. Wolves create an 'ecology of fear' (Ripple and Beschta, 2004) in which they regulate the lower levels of the trophic pyramid: elk stop venturing into both deeper thickets and open areas, out of fear of being attacked. ${ }^{1}$

In Europe, rewilders are more concerned with the restoration of large herbivores and their grazing regimes. In one high-profile example, Dutch ecologists introduced 'back-bred' and 'de-domesticated' cattle and horses (along with deer) into the Oostvaardersplassen: an undeveloped polder landscape in the suburbs of Amsterdam. This experiment sought to reintroduce a 'naturalistic grazing regime' analogous to that performed by the aurochs and tarpan at the start of the Holocene (c. 10000 BP) (Vera, 2009). The ecologists argued that left to their own devices these animals would create a 'shifting mosaic' of forest pasture landscapes, not the closed canopy forest that is currently held to be the natural ecology for the region (Vera, 2000). Populations of cattle and horses grew quickly at the Oostvaardersplassen and animals began dying of starvation. There were protests from animal welfare organisations and a compromise solution was arrived at in which the human ranger 'becomes wolf'. Armed with a rifle and criteria for assessing (farm) animal welfare he seeks to cull those animals that are judged not to be able to make it through the winter (Lorimer and Driessen, 2014). The site has been judged as too small for actual wolf reintroduction. In this 'proactive predator simulation model' the ranger performs the lethal agency of wolves. But it has not been possible to replicate the landscape scale ecology of fear that is believed to have reverted the trophic cascade at Yellowstone.

\section{Reworming}

Popular anxieties about declines and absences in the microbiome are more recent. 
During the $19^{\text {th }}$ and $20^{\text {th }}$ century microbes were generally cast as pathological 'germs' in need of eradication. Recent developments in the science and technology of metagenomics (the genetic sequencing of samples gathered from the wider environment) have helped map the abundance of microbial life associated with human bodies (Turnbaugh et al., 2007). Medical research increasingly points to the functional importance of the human microbiome. This work intersects with preexisting hypotheses that link the rise of allergy, autoimmune and inflammatory disease to the excesses of hygiene and the demise of our 'old friends' (Rook and Brunet, 2005). Theorists suggest that the absence of microbial organisms with which we evolved, unsettles basic bodily systems that enable metabolism, immunity and even cognition (Blaser and Falkow, 2009). The result is widespread dysbiosis (Logan et al., 2016). There is still a great deal of basic science to be done on the microbiome and the discussion of translational applications is speculative and full of hype. Paxson and Helmreich note a general 'microbiomania' that has gripped the life sciences in which microbes figure as 'tokens' of an underdetermined biology 'full of yet-to-be explored possibility’ (Paxson and Helmreich, 2014: 166). ${ }^{2}$

Nonetheless, this thinking has informed a collection of scientific and other experiments in 'biotherapy' (Grassberger et al., 2013): the therapeutic use of nonhuman organisms to manage the ecologies of the human microbiome. These include ‘faecal transplants' to shift antibiotic resistant bacteria (Spector and Knight, 2015) and 'vaginal seeding' to replicate birth canal bacterial colonisation for babies born by Caesarean section (Dominguez-Bello et al., 2016). They encompass various pro- and pre-biotic diets designed to work on the gut microbiome, and novel personal and domestic hygiene products that actively seed the skin and built environment with 
stable colonies of 'good bacteria'. ${ }^{3}$

Human helminths have emerged as a prominent set of old friends. These animals are common to humans and have long history of coevolution. Deworming has been central to programmes for global health and economic development (Ettling, 2013), as high wormloads have been linked to a range of health and productivity problems (Bethony et al., 2006). Human helminths have largely been eradicated (along with a host of other microbes) in the Global North, as a result of broader initiatives to control infectious disease. But they persist in large areas of the rural Global South and helminth disease (helminthiasis) remains a global health problem (Hotez et al., 2008).

In the last fifteen years several thousand generally affluent, urban and well-educated patients have begun reworming: using species like human hookworm (Necator americanus) therapeutically to tackle conditions such as hay fever, inflammatory bowel disease and even autism (Cheng et al., 2015). Studies in animal models and human clinical trials are underway (Wammes et al., 2014; Maizels, 2016), but these have been overtaken by a burgeoning 'hookworm underground' (Velasquez-Manoff, 2012). This online community links patients, researchers and advocates who share and sell animals, equipment and expertise.

Research suggests that some helminths can enter into symbiotic relationships with their human host. After an initial, generally unsuccessful, effort to shift the worms the body learns to tolerate a bearable wormload. Worms seem able to regulate and downgrade the host immune system to enable their persistence (Allen and Maizels, 2011). Microbiologists suggest that helminths can manipulate the microbial ecologies 
of their host for their own ends, in ways that might explain immune modulation (Versini et al., 2015). Some researchers envisage helminths as 'keystone species' (Bilbo et al., 2011), 'talking’ to bacteria (Zaiss et al., 2015), and engaged in acts of ‘diplomacy’ (Steinfelder et al., 2016) with their hosts, who in turn now figure as 'tolerating' or even 'actively recruiting' microbes to maintain health (Gilbert et al., 2012).

In controlled political and ecological condition some helminths have thus been recast as 'gut buddies' - salutary symbionts capable of recalibrating dysfunctional bodily relationships (Lorimer, 2016b). One provider of therapeutic helminths suggests that worms serve to 'calibrate' and then 'exercise' the immune system, keeping it sufficiently busy or distracted to avoid it turning against itself (Biome Restoration, 2016). Some advocates speak of the 'rewilding' of the human microbiome (Leach, 2015). They position these interventions as forms of 'evolutionary medicine' that detect and address 'evolutionary mismatches' between the ecological composition of human bodies and the external environments to which they are exposed (Parker and Ollerton, 2013). The science and the clinical trials that might make helminth therapy mainstream are still in their early stages. The field is subject to some of the hype associated with the microbiomania identified above. Many of those taking worms outside the trials recount transformations in their health and respite from conditions that are currently poorly managed even where patients have access to state-of-the-art immune-suppressant drug regimes (for a review see Liu et al., 2016).

\section{Ecological ontologies}

Although they range across scales and knowledge and policy domains, these 
interventions share four components of a common ontology. The first is an ecological conception of life. This is concerned more with the processes of movement, circulation and interaction, than with the essential character and composition of its constituent forms. Nonhuman species are secondary to the functions and services they deliver through their systemic effects. To differing degrees, wolves, cows and worms are valued for their ecological roles, rather than their rarity, authenticity, or charisma in interspecies encounters. Humans and other animals are folded into (and even become) ecological 'milieux' (after Foucault, 2007: 20-21). This is an entangled ontology of 'multispecies becomings with' (Haraway, 2008). Diverse relations are targeted in these interventions. They span the epigenetic and symbiotic molecular interactions through which hookworms deliver immunity, the selective grazing preferences of herbivores that are shaped and communicated by plants, and the ecologies of fear (and calm or even boredom) configured by predator presence and absence.

Second, these ecologies are nonequilibrium. There is no timeless balance of nature in these examples. Instead, these ecologies involve ‘interaction webs’ (Estes et al., 2011: 13) that are marked by relations of differing intensities. These webs are spaced through extensive connections and are understood to be 'metastable': capable of moving between, and conforming to, alternative stable states (Eisenberg, 2010). Examples might include a shift from a forest to a savannah landscape, or the emergence of an inflammatory disease like Crohn's. The passage between these states is marked by 'thresholds' and 'tipping points' (Groffman et al., 2006). In the cases of rewilding and reworming, these changes in state are associated with local species extinctions. These ecologies show hysteresis, in that they do not necessary move 
equally easily into and out of different states as a result of the return of absences. There is a great deal of contingency and complexity within these webs, which are animated by ‘discordant harmonies’ (Botkin, 1990).

In some ways this ontology is akin to that identified in recent critical writings on environmental and biological security (Braun, 2014; Massumi, 2009; Hinchliffe et al., 2013). Massumi notes how "the figure of the environment shifts: from the harmony of a natural balance to a churning seed-bed of crisis in the perpetual making” (2009: 154). What is different in the specific relations examined here is the significance of absences (rather than excessive presences) as the cause of environmental pathologies. It is the absence of ecological components that causes problems, unlike the anticipated security crises that stem from an overly energised global climate, or the biosecurity risks of emerging infectious diseases in intensive and globalised agriculture. Ecologies subject to rewilding and reworming are already tipped into disaster and in need of proactive transformation.

A common absence provides the third connecting component in this ontology. This is captured by the figure of the keystone species. These 'strongly interactive' (Soulé et al., 2005) animals control the dynamics of an ecosystem. Ecologists and immunologists first became aware of the pathological absences of wolves and worms through detections of their 'ghostly' presence in dysfunctional relations. In nature reserves, the absence of species that would have performed functions like predation, pollination, dispersal and germination is understood to generate 'anachronisms': species and ecologies with rhythms ill attuned to their contemporary context (for a discussion see Barlow, 2000). Similar thinking informs the microbiologists and 
immunologists who link the autoimmune effects of missing microbes to 'evolutionary mismatches' between the host and their absent symbionts (Parker and Ollerton, 2013). They suggest that the absence of the calibrating agencies of keystone species makes the system go awry and causes dysbiosis. In this holistic formulation parts of a once functional ecology are seen to turn against the wider 'self'- be it the human superorganism or the nature reserve. The ecology in question subsequently changes state, becoming inflamed, autoimmune or lacking in resilience.

Fourth, these interventions remain centred on securing valued versions of human life. But they recognise this to be fundamentally entangled with the nonhuman world in all its biological, geological and technological diversity. Rewilding and reworming share a more-than-human ontology that links the planetary to the microscopic. On the macro scale, rewilding in being shaped by discourses around the Anthropocene: that (some) humans have become a geological force, shaping the evolutionary conditions for future planetary wilds. Multiple future natures are possible and these will emerge in conditions far from the purified wilderness. Similarly, the figure of the human as a degraded superorganism, flags the ontological significance of the non-us in us. Being human is presented as a multispecies achievement (Haraway, 2016). Mobile microbes link us with each other, our domestic animals and the wider environment. The human is folded into a micro-ontology (Hird, 2009) of porous bodies and lateral exchange. This ontostory radically redistributes agency. It recognises both the risks and the 'corporeal generosity’ (Diprose, 2002) of the microbes that shape our thoughts, feelings and sociabilities.

\section{A probiotic environmentality}


Work on biosecurity (e.g. Massumi, 2009; Braun, 2014) connects this ecological ontology to a mutation in late modern modes of government, first detected by Michel Foucault in the 1970s. Foucault (2010) briefly identifies the emergence of 'environmentalities', or forms of an 'environmental' mode of biopower in his lectures on neoliberalism and government in conditions of crisis. Subsequent commentators have developed this concept in ways that are helpful for understanding the modes of government associated with the probiotic turn.

We can contrast environmentalities with sovereign and disciplinary power - whose focus is on the human body or subjectivity - and regimes of biopolitics, concerned with governing life at the scale of the population. ${ }^{4}$ Instead, Anderson explains that, “environmentalities work through systematic modifications of the 'environment' within which an action occurs, rather than directly on the body’s capabilities” (Anderson, 2012: 39). He suggests that: “an environmentality is a logic that functions on a far-from-equilibrium environment by modulating the aleatory (chance or random) human and non-human processes that make up that environment” (Anderson, 2011: 232). Wakefield and Braun note that this mode of government involves: "not just the government of integrated and highly technologized socioecological systems, but government through such systems, such that it is no longer clear that government in any way seeks to produce subjects as it did before. Government, from this view, is as much about managing circulation and modulating flows as it is about molding individuals” (Wakefield and Braun, 2014: 5).

Writing about the environmentality of probiotic forms of urban flood management, Braun identifies a 'decidedly fluid and flexible landscape' of biopower in which 
“things are permitted to 'flow' and natural processes are allowed to 'function', such that nature's diversity provides the 'service' of cancelling out the very risks that nature itself presents in an age of anthropogenic climate change. One does not work against nature, as with modernist design concepts; rather, one works with it” (2014: 58-9). He suggests that this account:

Reverses a common story about ‘sustainable' or 'resilient’ urbanism that assumes that what we are witnessing today is a long-overdue adaptation of urban life to the unpredictable rhythms of the ecological world ... rather, it is that governing through the naturalness of nature at the scale of the city must be understood as a particular mode of government, one that may be less of a departure from already existing modes than an extension of a particular apparatus in which molding life is replaced by modulating natural processes, now extended to include the nonhuman world itself (2014: 60).

The 'environmental' character of this mode of biopower relates to its ecological interventions to modulate the milieux within which subjects come into existence. An environmental mode biopower can be differentiated from forms of power identified in recent Foucauldian work in animal and multispecies studies. This research has largely been concerned with either forms of disciplinary power at work on individual animal bodies and subjectivities (e.g. Holloway, 2007), or with the biopolitics of various forms of animal management targeted at the scale of the breed or species (e.g. Biermann and Mansfield, 2014). 
The concept of environmental biopower resonates more with discussions of the ‘microbiopolitics’ (Paxson, 2008) or ‘symbiopolitics’ (Helmreich, 2009) of governing microbial relations. Paxson (2008) has examined probiotic forms of microbiopolitics in her work on the human-microbial relationships associated with the raw milk cheese movement in the USA. She describes these as 'post-Pasteurian' (rather than antiPasteurian). Paxson explains that: “post-Pasteurianism takes after Pasteurianism in taking hygiene seriously. It differs in being more discriminating” (2014: 118). Her analysis is echoed in writings by Keulartz (2012) on rewilding and probiotic forms of flood management in the Netherlands. Keulartz argues that these involve the “controlled decontrolling of ecological controls” (2012:16) to enable landscape scale interventions that shift the ecological and biophysical intensities within which nonhuman actors come into being.

Rewilding and reworming can be understood to involve environmental forms of biopower that depart in interesting ways from those reported in the limited literature on biosecurity (reviewed above). The primary 'environmental' political technology deployed is the strategic use of keystone species. While wolves and cows (and to a much lesser extent) worms are disciplined as individuals and governed as species (biopolitics), those concerned with their reintroduction are primarily interested in their ecological or 'environmental' agencies. As ‘ecological engineers' and 'gut buddies' they are valued for their abilities to modulate or recalibrate dysfunctional ecologies. They enable human 'rewilders' to attempt ecosystem-level change to redress 'trophic cascades' or 'evolutionary mismatches'. The hope is that the target ecosystem has limited hysteresis and can be tipped (back) over a threshold towards one in which the rhythms of its constituent circulations can be synchronised to deliver desired 
functionality. Worms and wolves are introduced to modulate the specific milieux of the human body or the nature reserve by shifting ecological intensities and channelling flows to secure desired circulations.

While the 'antibiotic' practices of modern hygiene and wildlife conservation seek to head off a change in phase state to preserve homeostasis and equilibrium, probiotic environmentalities seek to initiate transformative events. The aim is to work with and modulate the emergent properties of interspecies interaction webs to reconfigure the basic conditions in which life persists. Probiotic environmentalities seek thresholds and try to tip systems across them. On the one hand, these interventions are akin to practices of (bio)security, which in Anderson's terms 'act in relation to the contingencies of life by attempting to seize possession of the future before it occurs and shaping how contingent decisions or events will unfold' (2012: 39). Where they differ is in relation to the temporality of the crisis to which they respond. While forms of biosecurity seek to manage circulations to build resilience in the face of imminent but unavoidable disaster, probiotic approaches figure the present as already disastrous. They seek to reverse, restore or otherwise address deleterious existing transitions.

\section{Transformative environmentalities?}

This reading opens up environmentalities that challenge the status quo. Existing work has tended to align the prevalent practices of biosecurity and the biopolitics of resilience with the logics of neoliberalism, anthropocentrism and neocolonialism. In the final section of this analysis I will begin to explore the critical potential of the probiotic turn, examining the ways in which the deliberate pursuit of tipping points 
can both sustain and transform political and ecological relations. There are many different axes along which one might look to specify the probiotic turn. Here I will focus first on questions of political economy, before turning to questions of anthropocentrism and human-nonhuman relations.

\section{Probiotic political economies}

We can start by noting the geographies of whose lives are secured and whose are abandoned in these probiotic interventions. There are striking and unequal political ecologies to rewilding within and without the human body. Access to 'antibiotic' forms of healthcare and environmental management is still globally patchy. While probiotic interventions to remedy their consequences are driven by political and economic elites of the Global North. For example, in the $20^{\text {th }}$ century helminthiasis was strongly associated with colonial plantation economies. Here the poor sanitation, nutrition and healthcare of indentured labour gave rise to extreme levels of infection intensity (Palmer, 2009). Hookworm disease was presented as a productivity problem for colonial capitalism and was tackled through sanitation and drug delivery (Ettling, 2013). Helminthiasis is now largely absent in the Global North. Instead it is classified as a 'neglected tropical disease' that is strongly associated with impoverished and abandoned populations in the rural Global South (Hotez, 2013). Meanwhile the epidemics of absence linked to missing microbes can no longer be understood as diseases of affluence that are confined to the Global North. Allergies and autoimmune conditions increasingly affect people in the urban Global South.

Rewilding in northern temperate regions has largely become possible due to economic globalisation and agricultural intensification. Agriculture and forestry have shifted to 
the tropics, thus freeing up space for nature in lieu of land (often appropriated) elsewhere. Rewilding is made possible by regional, but not global 'decoupling'. There may be no net gain for biodiversity as a consequence of the probiotic shift. Meanwhile those in the North who abandon former farmland and make space for the wild are often politically and economically marginal (Schwartz, 2006). The same is true of those who live in close proximity to resurgent predators. In spite of much hype, local residents are rarely the main beneficiaries of emerging forms of wildland ecotourism (Hintz, 2007).

Divergent political economies can also be identified if we attend to the human beneficiaries of the different proprietorial relations associated with rewilding. Early advocates of both reworming and rewilding were informed by a clear, ‘transformative' (after Nelson, 2014) commitment to common property in the reorientation of hygiene and land management. Rewilding schemes in the macrobiome have largely taken place on public land. The social and ecological benefits they sought to secure were framed as for the common good. The North American rewilding movement has roots in radical ecology (Foreman, 2004) - albeit of a deep green, and at times anti-humanist, inclination (Jørgensen, 2015). While some of the main European advocates link rewilding to a socially democratic project for land reform, public access and the generation of new models of environmental citizenship (see Monbiot, 2013). Likewise, those responsible for providing organisms and advice through the 'hookworm underground' largely do so at cost (Lorimer, 2016). This is primarily a communitarian and voluntarist activity. It is premised on a gift economy that secures a reservoir of known worms amidst a population of willing 
donors. Many of the citizens and scientists working with whole organisms want to keep these biotechnologies in the public domain.

However, one does not have to look far to detect tendencies towards private property in the probiotic turn. This is expressed through a desire to enclose the generative agencies of keystone species and to value their nonhuman labour as forms of 'lively capital’ (see Cooper, 2008; Barua, 2016). Some government agencies, environmental NGOs and private landowners are actively seeking ways of bringing the 'ecosystem services' delivered by rewilding to market. We are told of the flood mitigation value of beavers (Sandom and MacDonald, 2015), the carbon sequestration potential of deextinct mammoths (Zimov, 2005) and the potential of charismatic species for reconnecting alienated urban citizens in commodified ecotourist encounters (Rewilding Europe, 2012). Likewise, the decoding of the hookworm genome was propelled by a growing interest in the pharmaceutical industry in developing patentable molecular surrogates for the worms' 'secretome' (Ditgen et al., 2014). The hope is that these will sustain and enhance existing lucrative markets in immunosuppressant drugs. This proposed privatisation has sparked concern amongst some members of the hookworm underground. They fear that the communitarian character of helminth therapy will be forestalled by the desire to enclose and privatise it in pill form (Parker et al., 2012).

\section{Probiotic ecologies}

A second set of tensions relate to the potential of probiotic environmentalities to transform the anthropocentrism at the heart of modern antibiotic approaches to securing human and environmental health. The question here concerns the degree to 
which these alternative approaches work with ecological processes and forms of nonhuman difference in ways that respect animal subjectivities, and deliver diverse and flourishing ecologies. Even the most generous acts of interspecies care expressed in rewilding remain premised on securing the health of the human body. No one is giving themselves up as wolf prey or as a nature reserve for rare helminths. But important differences exist in what life is let live and what is made killable in different forms of rewilding.

Anthropocentrism persists most strikingly in situations in which the regenerative potential of keystone species is framed as a means to deliver 'resilient' socioecological systems. Here wildlife is reduced to a form of 'green infrastructure' (e.g. (Jepson and Schepers, 2016) engineered to deliver 'ecosystem services'. In this context, the specific forms, lived experiences and abundance of animals, plants and other nonhumans are secondary to the provision of anthropocentric functions. We find this tendency more clearly expressed in the microbiome. For example, projects to domesticate or genetically engineer a ‘designer helminth' (Parker et al., 2012), or to synthesise their molecular secretions, imagine future worlds in which the originary species have been eradicated. There is little concern here for microbial biodiversity, or for redressing the widespread microbial extinctions associated with the spread of modern hygiene.

More hospitable interspecies relations are expressed in the intercorporeal care extended by members of the hookworm underground to their 'gut buddies' (Lorimer 2016). In becoming responsible hosts, those reworming learn to be affected (after Despret, 2004) by their worms’ ecological preferences. They modify their diets, 
medicine and lifestyles to maximise the immune-suppression provided by their worms. Living well with worms requires attuning to their symbiont's demands, maintaining a living colony outside of the body, and staying in close contact with a network of reservoir host donors in the hookworm underground in case the worms die.

Comparable tensions are at play in the macrobiome. At one extreme, advocates envisage charismatic 'de-extinct' and 'back-bred' animals engineered for ecotourism (like Jurassic Park). Little consideration seems to be given to the social, behavioural and (microbial) contexts to which they might be returned. ${ }^{5}$ More conservationorientated futures are imagined for keystone species that might be introduced into sites far from their historic ranges to manage non-analogue novel ecosystems. Proposals include taking African elephants to Australia as biological control agents to graze invasive species of grass to which they are familiar from their home range (Bowman, 2012). Another future nature envisages African mammals translocated to North America as ecological surrogates for their now extinct taxonomic kin (Donlan et al., 2006). These hypothetical animal movements and reincarnations have recently become subject to much debate (Seddon et al., 2014; Adams, 2016; Robbins and Moore, 2013).

We can find a more transformative model of rewilding at sites like the Oostvaardersplassen in the Netherlands. Here reserve managers have sought to reconcile the interests of the large herbivores with those of the wider ecology they were introduced to restore. The practices of de-domestication, and the use of the predator simulation model to govern herbivore populations, offers a novel means of 
working with animal agencies to shape landscape ecologies. In these 'wild experiments' (Lorimer and Driessen 2014) large herbivores are given space to learn and socialise in situations in which the quality of wildness is not indexed to human absence, or held to be forever lost due to histories of domestication.

\section{Conclusions: Hospitality in the Anthropocene}

This paper has identified and illustrated a probiotic turn in late modern modes of government. This turn seeks to address the 'pathologies' associated with antibiotic ways of managing life by (re)introducing keystone species to reorganise a range of dysfunctional political ecologies. These interventions shift the intensities of these ecologies and aim to tip them towards a desired future state. Here the generative and disruptive potential of 'wildness' has been revaluated. The wild shifts from being 'the

monster at the door' (Davis, 2005) to a generative potential for creating desired 'postPasteurian’ ecologies. The probiotic turn has been situated within the broader emergence of environmental modes of biopower in the $21^{\text {st }}$ century. Probiotic environmentalities differ from the environmentalities of biosecurity in their proactive identification of tipping points. A brief review of the political economy and humannonhuman relations performed in the probiotic turn reveals its potential to both sustain and transform prevalent forms of governance.

I will conclude by positioning this argument more explicitly in the context of ongoing debates around hospitality and politics in the Anthropocene. The current intellectual fervor associated with the Anthropo-scene (Lorimer, 2016a) has distilled and amplified deep rifts in late modern biopolitical thought. The popular realisation that humans are inextricably folded into the Earth foregrounds the degree to which 
biopower becomes unavoidably 'environmental'. Any deliberate or inadvertent environmental intervention, from the bodily to the planetary scale, has the potential to configure the conditions under which life exists. Anthropocenic interventions configure which subjects and populations are made to live and let die. There can be no return to Nature, or retreat to bodily purity. Instead social and interspecies hospitality requires attention and intervention is unavoidable. The epochal proclamation of the Anthropocene represents a provocation. For some, it is a challenge to assume our Enlightenment destiny as the ‘God Species’ (Lynas, 2011). We can imagine a 'good Anthropocene' (Asafu-Adjaye et al., 2015) in which we design and implement grand schemes for planetary management. For critics, like Donna Haraway (2015), the name represents an 'extraordinary contradiction’ ${ }^{6}$, and a neocolonial, capitalist and patriarchal imposition at a time when human exceptionalism should be on the wane as political, conceptual and methodological categories.

In this spirit I would suggest that there is transformative potential in some dimensions of the probiotic turn for imagining and enacting more-than-human forms of hospitality in the Anthropocene. These practices help overcome the impasse identified by Cary Wolfe in existing approaches to environmental politics. These he argues are premised on either elevating animals (including humans) to the essential status of 'the person', or on dissolving animal subjects into a 'radically dedifferentiating discourse of "life”' (2012: 58). The former effaces animal difference, while the latter (which he find most clearly expressed in the writings of Robert Esposito) provides no grounds from which one can extend hospitality. Instead, he argues that hospitality is not unconditional, but it involves working through encounters, and with nonlinear 
ecological processes, to permit various forms of flourishing (after Haraway 2008). Wolfe's argument resonates with recent work on hospitality in multispecies studies that seeks to ground Derrida’s 'abstract' (Candea, 2012) conception of unconditional hospitality in the specific materialities of human and nonhuman relations (see van Dooren, 2016).

Thinking relationally with wolves and worms helps us grapple with the materialities and specificities of Anthropocene hospitality. Reworming and rewilding start from a basic 'immunitary' impulse to protect individual and aggregate forms of life. These include human bodies and charismatic species. But life is conceived as a field of ecological difference that can be made subject to forms of environmental biopower. In an environmental formulation immunity requires a communitarian (Esposito, 2011) form involving tolerance, accommodation or even the active recruitment of microbial mutualists. But these forms of companionship happen alongside more martial practices of control or even eradication. Probiotic relations with wolves and worms confirm that pathogens exist, but shows that their form is not essential (see Kelly, 2012). Instead, pathologies emerge out of particular political-ecological ‘configurations’ (Hinchliffe et al., 2016) in which both absence and excessive presence can cause problems. Hospitality thus becomes an ecological affair, performed through the choreography of 'polyphonic' (after Tsing 2015) and discordant spatio-temporal rhythms.

Situating deliberate re-entanglements like rewilding and reworming in their specific spatio-temporal configurations shows that we cannot analyse the probiotic turn outside of the violent colonial presents, and forms of political economy, within which 
it proceeds. There are spatial 'pathologies of power' (Farmer, 2004) that shape who is abandoned to neglected tropical and emergent non-communicable diseases, and who will benefit from emerging forms of helminthic therapy. Comparable pathologies shape which land is abandoned and expropriated to make space for rewilded ecologies. Yet rewilding does offer grounds for hope. Communal platforms for the exchange of worms, or the resurgence of wildlife in the (sub)urban ecologies of postindustrial cities, present unruly political ecologies and probiotic 'arts of living' (Tsing, 2015). The probiotic turn offers tentative means for imagining the Anthropocene as a 'boundary condition' (see Haraway, 2015): a key juncture in the transition towards a more hospitable epoch.

\section{Biography}

Jamie Lorimer is an Associate Professor in the School of Geography and the Environment at the University of Oxford. His research explores the histories, cultures and politics of scientific ways of knowing and governing Nature. He is the author of Wildlife in the Anthropocene: Conservation after Nature (Minnesota University Press). He currently running an interdisciplinary project developing participatory methods for mapping the domestic microbiome (see www.goodgerms.org).

\section{Acknowledgements}

Versions of this paper were presented at the SLSA conference in Houston and at a workshop in the School of Geosciences in Edinburgh. I am grateful to the organisers and audiences for their comments. The paper was significantly enhanced by the careful, critical and intelligent readings offered by three anonymous referees and the journal editors. Many thanks. 


\section{References}

Adams, William M. (2016) Geographies of Conservation I: De-Extinction and Precision Conservation. Progress in Human Geography.

Agrawal, Arun. (2005) Environmentality : Technologies of Government and the Making of Subjects, Durham: Duke University Press.

Allen, Judith and Rick Maizels. (2011) Diversity and Dialogue in Immunity to Helminths. Nature Reviews Immunology 11: 375-388.

Anderson, Ben. (2011) Population and Affective Perception: Biopolitics and Anticipatory Action in Us Counterinsurgency Doctrine. Antipode 43: 205-236. Anderson, Ben. (2012) Affect and Biopower: Towards a Politics of Life. Transactions of the Institute of British Geographers 37: 28-43.

Asafu-Adjaye, J, Blomqvist, L, Brand, S, Brook, B, Defries, R, Ellis, E, Foreman, C, Keith, D, Lewis, M, Lynas, M, Nordhaus, T, Pielke, R, Pritzker, R, Roy, J, Sagoff, M, Shellenberger, M, Stone, R and Teague, P. (2015) An Ecomodernist Manifesto, Oakland: Breakthrough Institute.

Barlow, Connie (2000) The Ghosts of Evolution: Nonsensical Fruit, Missing Partners, and Other Ecological Anachronisms: Basic Books.

Barua, Maan. (2016) Lively Commodities and Encounter Value. Environment and Planning D: Society and Space.

Bethony, J., Brooker, S., Albonico, M., Geiger, S. M., Loukas, A., Diemert, D. and Hotez, P. J. (2006) Soil-Transmitted Helminth Infections: Ascariasis, Trichuriasis, and Hookworm. Lancet 367: 1521-1532.

Biermann, Christine and Becky Mansfield. (2014) Biodiversity, Purity, and Death: Conservation Biology as Biopolitics. Environment and Planning D: Society and Space 32: 257-273. 
Bilbo, Staci, Wray, Gregory, Perkins, Sarah and Parker, William. (2011)

Reconstitution of the Human Biome as the Most Reasonable Solution for Epidemics of Allergic and Autoimmune Diseases. Medical Hypotheses 77: 494-504.

Biome Restoration. (2016) The Science. Available at: http://biomerestoration.com/the-science/.

Blaser, Martin. (2014) Missing Microbes: How Killing Bacteria Creates Modern Plagues: Oneworld Publications.

Blaser, Martin and Falkow, Stanley. (2009) What Are the Consequences of the Disappearing Human Microbiota? Nat Rev Micro 7: 887-894.

Botkin, Daniel. (1990) Discordant Harmonies: A New Ecology for the Twenty-First Century, New York: Oxford University Press.

Bowman, David. (2012) Conservation: Bring Elephants to Australia? Nature 482: 3030.

Braun, Bruce. (2014) A New Urban Dispositif? Governing Life in an Age of Climate Change. Environment and Planning D: Society and Space 32: 49-64.

Candea, Matei. (2012) Derrida En Corse? Hospitality as Scale-Free Abstraction. Journal of the Royal Anthropological Institute 18: S34-S48.

Cheng, Anna, Jaint, Darshana, Thomas, Steven, Wilson, Janet and Parker, William. (2015) Overcoming Evolutionary Mismatch by Self-Treatment with Helminths: Current Practices and Experience. Journal of Evolutionary Medicine 3: 1-22.

Cooper, Melinda. (2008) Life as Surplus : Biotechnology and Capitalism in the Neoliberal Era, Seattle: University of Washington Press. 
Davis, Mike. (2005) The Monster at Our Door : The Global Threat of Avian Flu, New York: New Press.

Despret, Vincienne. (2004) The Body We Care For: Figures of Anthropo-ZooGenesis. Body \& Society 10: 111-134.

Diprose, Rosalyn. (2002) Corporeal Generosity: On Giving with Nietzsche, MerleauPonty, and Levinas, Albany: State University of New York Press.

Ditgen, Dana, Anandarajah, Emmanuela, Meissner, Kamila, Brattig, Norbert, Wrenger, Carsten and Liebau, Eva. (2014) Harnessing the Helminth Secretome for Therapeutic Immunomodulators. BioMed Research International 2014.

Dominguez-Bello, M. G., De Jesus-Laboy, K. M., Shen, N., Cox, L. M., Amir, A., Gonzalez, A., Bokulich, N. A., Song, S. J., Hoashi, M., Rivera-Vinas, J. I., Mendez, K., Knight, R. and Clemente, J. C. (2016) Partial Restoration of the Microbiota of Cesarean-Born Infants Via Vaginal Microbial Transfer. Nature Medicine 22: 250-253.

Donlan, C. J., Berger, J., Bock, C. E., Bock, J. H., Burney, D. A., Estes, J. A., Foreman, D., Martin, P. S., Roemer, G. W., Smith, F. A., Soule, M. E. and Greene, H. W. (2006) Pleistocene Rewilding: An Optimistic Agenda for Twenty-First Century Conservation. American Naturalist 168: 660-681.

Eisenberg, Cristina. (2010) The Wolf's Tooth: Keystone Predators, Trophic Cascades, and Biodiversity: Island Press.

Ellis, Erle. (2011) Anthropogenic Transformation of the Terrestrial Biosphere. Philosophical Transactions of the Royal Society A: Mathematical, Physical and Engineering Sciences 369: 1010-1035. 
Esposito, Roberto. (2011) Immunitas : The Protection and Negation of Life, Cambridge ; Malden MA: Polity.

Estes, J. A., Terborgh, J., Brashares, J. S., Power, M. E., Berger, J., Bond, W. J., Carpenter, S. R., Essington, T. E., Holt, R. D., Jackson, J. B. C., Marquis, R. J., Oksanen, L., Oksanen, T., Paine, R. T., Pikitch, E. K., Ripple, W. J., Sandin, S. A., Scheffer, M., Schoener, T. W., Shurin, J. B., Sinclair, A. R. E., Soulé, M. E., Virtanen, R. and Wardle, D. A. (2011) Trophic Downgrading of Planet Earth. Science 333: 301-306.

Esteves, Luciana. (2014) Managed Realignment : A Viable Long-Term Coastal Management Strategy? Springer Netherlands.

Ettling, John. (2013) The Germ of Laziness: Rockefeller Philanthropy and Public Health in the New South: Harvard University Press.

Farmer, Paul. (2004) Pathologies of Power: Health, Human Rights, and the New War on the Poor: University of California Press.

Foreman, David. (2004) Rewilding North America: A Vision for Conservation in the 21st Century: Island Press.

Foucault, Michel. (2010) The Birth of Biopolitics: Lectures at the College De France, 1978--1979: Picador.

Foucault, Michel. (2007) Security, Territory, Population : Lectures at the Collège De France, 1977-78, Basingstoke ; New York: Palgrave Macmillan : République Française.

Gabrys, Jennifer. (2014) Programming Environments: Environmentality and Citizen Sensing in the Smart City. Environment and Planning D: Society and Space 32: $30-48$. 
Gilbert, Scott, Sapp, Jan and Tauber, Alfred. (2012) A Symbiotic View of Life: We Have Never Been Individuals. Quarterly Review of Biology 87: 325-341.

Grassberger, M., Sherman, R.A., Gileva, O.S., Kim, C.M.H. and Mumcuoglu, K.Y. (2013) Biotherapy - History, Principles and Practice: A Practical Guide to the Diagnosis and Treatment of Disease Using Living Organisms: Springer.

Groffman, P. M., Baron, J. S., Blett, T., Gold, A. J., Goodman, I., Gunderson, L. H., Levinson, B. M., Palmer, M. A., Paerl, H. W., Peterson, G. D., Poff, N. L., Rejeski, D. W., Reynolds, J. F., Turner, M. G., Weathers, K. C. and Wiens, J. (2006) Ecological Thresholds: The Key to Successful Environmental Management or an Important Concept with No Practical Application? Ecosystems 9: 1-13.

Hajek, Ann. (2004) Natural Enemies: An Introduction to Biological Control Cambridge University Press.

Haraway, Donna. (2016) Staying with the Trouble: Making Kin in the Chthulucene: Duke University Press.

Haraway, Donna. (2015) Anthropocene, Capitalocene, Plantationocene, Chthulucene: Making Kin. Environmental Humanities 6: 159-165.

Haraway, Donna. (2008) When Species Meet, Minneapolis: University of Minnesota Press.

Helmreich, Stefan. (2009) Alien Ocean : Anthropological Voyages in Microbial Seas, Berkeley: University of California Press.

Hinchliffe, Steve, Allen, John, Lavau, Stephanie, Bingham, Nick and Simon Carter. (2013) Biosecurity and the Topologies of Infected Life: From Borderlines to Borderlands. Transactions of the Institute of British Geographers 38: 531-543. 
Hinchliffe, Steve, Bingham, Nick, Allen, John and Simon Carter. (2016) Pathological Lives: Disease, Space and Biopolitics, London: Blackwell.

Hintz, John. (2007) Some Political Problems for Rewilding Nature. Ethics, Place and Environment 10: 177-216.

Hird, Myra. (2009) The Origins of Sociable Life: Evolution after Science Studies, Basingstoke: Palgrave Macmillan.

HMP. (2012) Structure, Function and Diversity of the Healthy Human Microbiome. Nature 486: 207-214.

Hobbs, Richard, Higgs, Eric and Carol Hall. (2013) Novel Ecosystems: Intervening in the New Ecological World Order Wiley.

Holling, C. S. and Gary Meffe. (1996) Command and Control and the Pathology of Natural Resource Management. Conservation Biology 10: 328-337.

Holloway, Lewis. (2007) Subjecting Cows to Robots: Farming Technologies and the Making of Animal Subjects. Environment and Planning D-Society \& Space 25: 1041-1060.

Hotez, P. J., Brindley, P. J., Bethony, J. M., King, C. H., Pearce, E. J. and Jacobson, J. (2008) Helminth Infections: The Great Neglected Tropical Diseases. Journal of Clinical Investigation 118: 1311-1321.

Hotez, Peter. (2013) Forgotten People, Forgotten Diseases: The Neglected Tropical Diseases and Their Impact on Global Health and Development: ASM Press. Jepson, Paul and Frans Schepers. (2016) Making Space for Rewilding: Creating an Enabling Policy Environment. Rewilding Europe.

Jørgensen, Dolly. (2015) Rethinking Rewilding. Geoforum 65: 482-488.

Kelly, Ann. (2012) The Experimental Hut: Hosting Vectors. Journal of the Royal Anthropological Institute 18. 
Keulartz, Jozef. (2012) The Emergence of Enlightened Anthropocentrism in Ecological Restoration. Nature and Culture 7: 48-71.

Leach, Jeff. (2015) Rewild CreateSpace Independent Publishing Platform.

Liu, J., Morey, R. A., Wilson, J. K. and Parker, W. (2016) Practices and Outcomes of Self-Treatment with Helminths Based on Physicians' Observations. Journal of Helminthology: 1-11.

Logan, Alan C., Jacka, Felice N. and Prescott, Susan L. (2016) Immune-Microbiota Interactions: Dysbiosis as a Global Health Issue. Current Allergy and Asthma Reports 16: 13.

Lorimer, Jamie. (2016a) The Anthropo-Scene: A Guide for the Perplexed. Social Studies of Science.

Lorimer, Jamie. (2016b) Gut Buddies: Multispecies Studies and the Microbiome. Environmental Humanities 8: 57-76.

Lorimer, Jamie and Clemens Driessen. (2014) Wild Experiments at the Oostvaardersplassen: Rethinking Environmentalism in the Anthropocene. Transactions of the Institute of British Geographers: 169-181.

Lorimer, Jamie and Clemens Driessen. (2016) From “Nazi Cows” to Cosmopolitan “Ecological Engineers”: Specifying Rewilding through a History of Heck Cattle. Annals of the American Association of Geographers: 1-22.

Lorimer, Jamie, Sandom, Chris, Jepson, Paul, Doughty, Chris, Barua, Maan and Keith Kirby. (2015) Rewilding: Science, Practice, and Politics. Annual Review of Environment and Resources 40: 8.1-8.24.

Lynas, Mark. (2011) The God Species : How the Planet Can Survive the Age of Humans, London: Fourth Estate. 
Maizels, Rick. (2016) Parasitic Helminth Infections and the Control of Human Allergic and Autoimmune Disorders. Clinical Microbiology and Infection 22: 481-486.

Marris, Emma. (2011) Rambunctious Garden: Saving Nature in a Post-Wild World, New York, NY: Bloomsbury USA.

Massumi, Brian. (2009) National Enterprise Emergency: Steps toward an Ecology of Powers. Theory, Culture \& Society 26: 153-185.

Mech, Daniel. (2012) Is Science in Danger of Sanctifying the Wolf? Biological Conservation 150: 143-149.

Monbiot, George. (2013) Feral: Searching for Enchantment on the Frontiers of Rewilding: Penguin Books Limited.

Nelson, Sara Holiday. (2014) Resilience and the Neoliberal Counter-Revolution: From Ecologies of Control to Production of the Common. Resilience 2: 1-17. Palmer, Steven. (2009) Migrant Clinics and Hookworm Science: Peripheral Origins of International Health, 1840-1920. Bulletin of the History of Medicine 83: 676-709.

Parker, William and Jeff Ollerton. (2013) Evolutionary Biology and Anthropology Suggest Biome Reconstitution as a Necessary Approach toward Dealing with Immune Disorders. Evolution, Medicine, and Public Health 2013: 89-103.

Parker, William, Perkins, Sarah E., Harker, Matthew and Michael Muehlenbein. (2012) A Prescription for Clinical Immunology: The Pills Are Available and Ready for Testing. A Review. Current Medical Research and Opinion 28: 1193-1202.

Paxson, Heather. (2008) Post-Pasteurian Cultures: The Microbiopolitics of Raw-Milk Cheese in the United States. Cultural Anthropology 23: 15-47. 
Paxson, Heather. (2014) Microbiopolitics. In: Kirksey E. (ed) The Multispecies Salon. Durham: Duke University Press, 115-121.

Paxson, Heather and Helmreich, Stefan. (2014) The Perils and Promises of Microbial Abundance: Novel Natures and Model Ecosystems, from Artisanal Cheese to Alien Seas. Social Studies of Science 44: 165-193.

Pereira, Henrique and Laetitia Navarro. (2015) Rewilding European Landscapes: Springer International Publishing.

Rewilding Europe. (2012) Rewilding Europe: Making Europe a Wilder Place, Nijmegen: Rewilding Europe.

Ripple, William J. and Robert Beschta. (2004) Wolves and the Ecology of Fear: Can Predation Risk Structure Ecosystems? BioScience 54: 755-766.

Robbins, Paul and Sarah Moore. (2013) Ecological Anxiety Disorder: Diagnosing the Politics of the Anthropocene. Cultural Geographies 20: 3-19.

Rook, Graham and LR Brunet. (2005) Microbes, Immunoregulation, and the Gut. Gut 54: 317-320.

Rutherford, Stepahnie. (2011) Governing the Wild: Ecotours of Power: University of Minnesota Press.

Sandom, Chris and David MacDonald. (2015) What Next? Rewilding as a Radical Future for the British Countryside. In: MacDonald, David and Ruth Feber (eds) Wildlife Conservation on Farmland. Managing for Nature on Lowland Farms. Oxford: Oxford University Press, 291-316.

Schwartz, Katrina. (2006) Nature and National Identity after Communism : Globalizing the Ethnoscape, Pittsburgh, Pa.: University of Pittsburgh Press. 
Seddon, Philip, Griffiths, Christine J., Soorae, Pritpal S. and Doug Armstrong. (2014) Reversing Defaunation: Restoring Species in a Changing World. Science 345: 406-412.

Sonnenburg, Justin and Ercia Sonnenburg. (2015) The Good Gut: Taking Control of Your Weight, Your Mood, and Your Long-Term Health: Penguin Publishing Group.

Soulé, Michael E., Estes, James A., Miller, Brian and Douglas Honnold. (2005) Strongly Interacting Species: Conservation Policy, Management, and Ethics. BioScience 55: 168-176.

Spector, Tim and Rob Knight. (2015) Faecal Transplants. BMJ (Online) 351.

Steinfelder, S., O’Regan, N. L. and Hartmann, S. (2016) Diplomatic Assistance: Can Helminth-Modulated Macrophages Act as Treatment for Inflammatory Disease? PLoS Pathogens 12.

Svenning, Jens-Christian, Pedersen, Pil B. M., Donlan, C. Josh, Ejrnæs, Rasmus, Faurby, Søren, Galetti, Mauro, Hansen, Dennis M., Sandel, Brody, Sandom, Christopher J., Terborgh, John W. and Vera, Frans W. M. (2016) Science for a Wilder Anthropocene: Synthesis and Future Directions for Trophic Rewilding Research. Proceedings of the National Academy of Sciences 113: 898-906.

Terborgh, John and James Estes. (2010) Trophic Cascades: Predators, Prey, and the Changing Dynamics of Nature: Island Press.

Tsing, Anna Lowenhaupt. (2015) The Mushroom at the End of the World: On the Possibility of Life in Capitalist Ruins: Princeton University Press.

Turnbaugh, Peter, Ley, Ruth, Hamady, Micah, Fraser-Liggett, Claire, Knight, Rob and Gordon, Jeffrey. (2007) The Human Microbiome Project. Nature 449: 804-810. 
van Dooren, Thom. (2016) The Unwelcome Crows. Angelaki 21: 193-212.

Velasquez-Manoff, Moises. (2012) An Epidemic of Absence: A New Way of

Understanding Allergies and Autoimmune Diseases: Scribner.

Vera, Frans. (2000) Grazing Ecology and Forest History, Wallingford Oxon, UK:

CABI Publishing.

Vera, Frans. (2009) Large-Scale Nature Development - the Oostvaardersplassen. British Wildlife.

Versini, Mathilde, Jeandel, Pierre-Yves, Bashi, Tomer, Bizzaro, Giorgia, Blank, Miri and Shoenfeld, Yehuda. (2015) Unraveling the Hygiene Hypothesis of Helminthes and Autoimmunity: Origins, Pathophysiology, and Clinical Applications. BMC Medicine 13.

Wagner, Stephen. (2010) Keystone Species. Nature Education Knowledge 3: 51.

Wakefield, Stephanie and Braun, Bruce. (2014) Guest Editorial. Environment and Planning D: Society and Space 32: 4-11.

Wammes, Linda, Mpairwe, Harriet, Elliott, Alison and Yazdanbakhsh, Maria. (2014) Helminth Therapy or Elimination: Epidemiological, Immunological, and Clinical Considerations. The Lancet Infectious Diseases 14: 1150-1162.

Wolfe, Cary. (2012) Before the Law: Humans and Other Animals in a Biopolitical Frame: University of Chicago Press.

Wuerthner, George, Crist, Eileen and Tom Butler. (2014) Keeping the Wild: Against the Domestication of Earth: Island Press.

Zaiss, Mario M, Rapin, Alexis, Lebon, Luc, Dubey, Lalit Kumar, Mosconi, Ilaria, Sarter, Kerstin, Piersigilli, Alessandra, Menin, Laure, Walker, Alan W, Rougemont, Jacques, Paerewijck, Oonagh, Geldhof, Peter, McCoy, Kathleen D, Macpherson, Andrew J, Croese, John, Giacomin, Paul R, Loukas, 
Alex, Junt, Tobias, Marsland, Benjamin J and Harris, Nicola L. (2015) The

Intestinal Microbiota Contributes to the Ability of Helminths to Modulate

Allergic Inflammation. Immunity 43: 998-1010.

Zimov, Sergei. (2005) Pleistocene Park: Return of the Mammoth's Ecosystem.

Science 308: 796-798.

\section{Notes}

\footnotetext{
${ }^{1}$ The landscape-scale effects of wolf reintroduction and the relative importance of an ecology of fear is currently the subject of some debate. For a review see Mech (2012).

2 The UC Davis Microbiologist Jonathan Eisen runs a popular blog, focused in part on calling out occurrences of 'overselling the microbiome'. See https://phylogenomics.blogspot.co.uk/.

${ }^{3}$ Examples include www.motherdirt.com and www.pro-b.co.uk

${ }^{4}$ It is important to differentiate this understanding of environmentalities from existing conceptions of this term, resulting from the application of Foucault's work on governmentality to situations in which forms of environmental power/knowledge shape particular environmental subjects (e.g. Agrawal 2005, Rutherford, 2011). For a discussion, and further application of this concept see Gabrys (2014).

${ }^{5}$ See for examples Stuart Brand's Long Now Foundation De-Extinction project entitle Revive and Restore http://longnow.org/revive/

${ }^{6}$ I take this quote from a lecture by Donna Haraway at UC Santa Cruz, entitled "Anthropocene, Capitalocene, Chthulucene: Staying with the Trouble" http://vimeo.com/97663518
} 